Sains Malaysiana 49(10)(2020): 2425-2432

http://dx.doi.org/10.17576/jsm-2020-4910-08

\title{
Glomus mosseae Promotes Xanthium italicum Invasion
}

(Glomus mosseae Menggalakkan Pencerobohan Xanthium italicum)

TANG Jie ShI, ZHAO ZHI LONG \& MA MiAO*

\section{ABSTRACT}

The relationship between mycorrhizal fungi and the invasiveness of alien plants is a controversial issue in plant invasion ecology. In this study, we investigated the influence of the mycorrhizal fungus Glomus mosseae on the physiological ecology, growth, and reproductive capacity of Xanthium italicum Moretti. We found that the relative chlorophyll content and net photosynthetic rate of the leaves of potted X. italicum whose rhizosphere soil was supplemented with G. mosseae was higher than those of the control group. Plants in the treatment group had longer root length and plant height; increased root, stem, and fruit biomass; and more male and female inflorescences and fruits relative to control plants. Additionally, the ratio of female to male inflorescence number was close to 2:1 in the treatment group as compared to 1:1 in the control group, suggesting an enhanced reproductive capacity in the former. G. mosseae applied to the soil also increased phosphorus absorption and accumulation in the roots, stems, and leaves of X. italicum. Thus, G. mosseae promotes the growth and reproduction of $\mathrm{X}$. italicum and thereby enhances its competitiveness and capacity for colonizing a new habitat.

Keywords: Alien plant; biological invasion; Italian cocklebur; mycorrhizal fungi

\section{ABSTRAK}

Hubungan antara kulat mikoriza dan keserbuan tumbuhan asing adalah isu kontroversi dalam ekologi pencerobohan tumbuhan. Dalam kajian ini, kami mengkaji pengaruh kulat mikoriza Glomus mosseae pada ekologi fisiologi, pertumbuhan dan keupayaan pembiakan Xanthium italicum Moretti. Kami mendapati bahawa kandungan klorofil relatif dan kadar fotosintesis bersih daun $\mathrm{X}$. italicum pot yang tanah rizosferanya dilengkapi dengan $\mathrm{G}$. mosseae lebih tinggi daripada kumpulan kawalan. Tumbuhan dalam kumpulan rawatan mempunyai panjang akar dan ketinggian tanaman yang lebih panjang; peningkatan biojisim akar, batang dan buah; dan lebih banyak perbungaan dan buah jantan dan betina berbanding tanaman kawalan. Selain itu, nisbah bilangan perbungaan betina dan jantan mendekati 2:1 dalam kumpulan rawatan berbanding 1:1 pada kumpulan kawalan, menunjukkan peningkatan keupayaan pembiakan pada kumpulan rawatan. G. mosseae yang digunakan pada tanah juga meningkatkan penyerapan dan pengumpulan fosforus pada akar, batang dan daun X. italicum. Oleh itu, G. mosseae mendorong pertumbuhan dan pembiakan $\mathrm{X}$. italicum dan dengan itu meningkatkan daya saing dan keupayaannya untuk menjajah habitat baru.

Kata kunci: Kerang Itali; kulat mikoriza; pencerobohan biologi; tumbuhan asing

\section{INTRODUCTION}

Mycorrhiza can improve the ability of alien plants to absorb water and inorganic salts (Brundrett 2009) and enhance their resistance (Wang et al. 2001) and competitiveness (Fumanal et al. 2006) while promoting their growth and reproduction (Chmura et al. 2012), allowing them to successfully invade a new habitat. However, other studies have found no correlation between mycorrhizal fungi and alien plant growth (Bunn 2015). Arbuscular mycorrhizal fungi are widely distributed and affect about $90 \%$ of vascular plants on Earth (Harley 2008). Their main functions are to promote the absorption of mineral elements by host plants, increase the resistance of host roots to harmful pathogens, and enhance plant resistance to extreme conditions such as high temperature, high salt, and water shortage. It can also improve photosynthetic efficiency and promote growth and biomass accumulation in the host (Zhi 2003). As one of the most common 
arbuscular mycorrhizal fungi, Glomus mosseae plays an important role in the successful invasion of alien plants.

Xanthium italicum Moretti is an annual herbaceous plant of the genus Xanthium in the Compositae family exhibiting high reproductive capacity (Lin et al. 2018), strong ecological adaptability (He \& Ma 2018) and allelopathic inhibitory activity (Shao et al. 2012), and interspecific competitiveness (Takakura 2010) that has caused serious harm to local agricultural production (Kazinczi 2009). Moreover, the toxicity of stems and leaves (Yang et al. 2006) and the strong adhesion of fruits to animal fur (Qu et al. 2015) threaten the health and development of local livestock. X. italicum is native to North America but has spread to many countries and regions in South America, Europe, Asia, and Oceania (Liu et al. 2008), and has been classified as a malignant invasive plant by many countries. It is unclear whether $G$. mosseae has contributed to the expansion of $X$. italicum populations since the mechanism of invasion of this plant is not well understood.

To answer this question, in this study we investigated the influence of $G$. mosseae on the relative chlorophyll content, photosynthetic response, root length, plant height, biomass, number of male and female inflorescences, and phosphorus content of potted X. italicum.

\section{MATERIALS AND METHODS}

\section{SEED COLLECTION}

$X$. italicum exhibits interspecific hybridization and pollination (Lin et al. 2018). In order to eliminate the influence of genetic differences among individuals on the results, a total of 660 mature fruits were collected on the individual self-fertilized and stored them at $-20{ }^{\circ} \mathrm{C}$.

\section{SEEDLING CULTURES}

Five plastic pots $(80 \times 60 \times 20 \mathrm{~cm})$ were filled up to 15 $\mathrm{cm}$ with river sand sterilized by high pressure. Seeds of healthy $X$. italicum of similar size were evenly sown in the sand with a spacing of $10 \mathrm{~cm}$ at a depth of $1 \mathrm{~cm}$, and a total of 175 seeds were sown. The relative humidity of the sand was about $70 \%$. The pots were covered with a colorless transparent plastic film to increase the temperature of the sand and reduce water evaporation, and the pots were placed in an open area of Shihezi University. The plastic film was removed when about $80 \%$ of seeds had germinated (i.e. the seedlings were unearthed). The pots were weighed daily to replenish the water (Aminah et al. 2013).

\section{SEEDLING TRANSPLANTATION}

Forty seedlings of the same height were selected for transplantation to plastic pots with a diameter of $25 \mathrm{~cm}$ and a height of $28 \mathrm{~cm}$ containing sterilized sand (river sand: clay $=1: 1$, with one seedling per pot. G. mosseae spores were incubated up to 5 days at $30^{\circ} \mathrm{C}$ on PDA (Potato dextrose agar) medium for inoculation. A 5-mm diameter PDA plug of $G$. mosseae was placed on seedling roots in twenty replicate pots. Control seedlings were inoculated with sterile PDA plugs. The Genbank accession number of $G$. mosseae is JF276414. The pots were randomly placed in an open area of the campus with adjacent pots separated by $40 \mathrm{~cm}$ to ensure that each seedling received full sunlight. The position of the pots was changed randomly once a week. Each plant was watered daily $(200 \mathrm{~mL})$ at 9 am and $8 \mathrm{pm}$. Measurements were made 60 days after transplantation (Al-Hammadi et al. 2018).

\section{DETERMINATION OF REATIVE CHLOROPHYLL CONTENT AND GENERATION OF PHOTOSYNTHESIS-PHOTORESPONSE CURVE}

The first fully expanded leaf at the top of each plant was selected for the measurement of relative chlorophyll content using a portable chlorophyll meter (SPAD-502 Plus; Konica Minolta, Tokyo, Japan). The photosynthesisphotoresponse curve of the leaves without disease and insect pests were measured using a portable photosynthesis meter (LI-6400; LI-COR, Lincoln, NE, USA). The photosynthetic active radiation gradient was set to 2000 , $1800,1600,1400,1200,1000,800,600,400,200,100,50$, 25 and $0 \mu \mathrm{mol} \cdot \mathrm{m}^{-2} \cdot \mathrm{s}^{-1}$, respectively. The concentration of $\mathrm{CO}_{2}$ was provided by the small cylinder, the concentration was set to $400 \mu \mathrm{mol} \cdot \mathrm{m}^{-2} \cdot \mathrm{s}^{-1}$, and the relative humidity was $70 \%$. Photosynthetic indexes such as light saturation point (LSP) and light compensation point (LCP) were fitted and calculated according to the right-angle hyperbolic modified model of leaves. Ten leaves were sampled for relative chlorophyll content and net photosynthetic rate measurements in the treatment group and control group respectively, and each measurement was repeated three times. (Zhang et al. 2014).

\section{DETERMINATION OF PLANT GROWTH-RELATED PARAMETERS}

Plants were carefully harvested so as not to disturb the roots and washed with distilled water to remove residual soil particles. All growth parameters were recorded first before the plants were dried in the oven for dry weight measurement. Root length and plant height were measured by a ruler, and male and female inflorescences were identified by the naked eye. The biomass (dry weight) of each organ was measured by analytical balance after all organs were dried in a constant temperature oven $\left(70{ }^{\circ} \mathrm{C}\right)$ for $48 \mathrm{~h}$. Both the treatment group and the control group contained ten replicates (He et al. 2017). 


\section{DETERMINATION OF PHOSPHORUS CONTENT IN VARIOUS ORGANS OF PLANTS}

Dried roots, stems, and leaves were crushed into powder, respectively, and different organs were placed separately. Accurately weighed $0.2 \mathrm{~g}$ of dry samples of each organ, put them in a $150 \mathrm{~mL}$ flask and added 15 $\mathrm{mL}$ mixed acid (concentrated $\mathrm{HNO}_{3}: \mathrm{HClO}_{4}=3: 1$ ), then, heated and digested them on an electric hot plate in the ventilation cupboard. When the sample blackens and white smoke comes out, removed the triangle bottle and added concentrated $\mathrm{HNO}_{3} 1 \mathrm{~mL}$ to continue heating and decomposition until the solution becomes clear. Moved the contents into a $100 \mathrm{~mL}$ volumetric bottle without damage, and diluted it to the scale with distilled water and shake well to clarify. Absorbed the supernatant $2 \mathrm{~mL}$ in a $50 \mathrm{~mL}$ volumetric flask, and added distilled water to $30 \mathrm{~mL}$. Added two drops of dinitrophenol indicator, and used $6 \mathrm{~mol} / \mathrm{L}$ sodium hydroxide solutions to a yellowish color ( $\mathrm{pH} \approx 7$ ), then added $5 \mathrm{~mL}$ ammonium molybdateammonium metavanadate chromogenic solution, diluted to the scale with distilled water and mixed well. After $30 \mathrm{~min}$, the absorbance was determined by colorimetry at the wavelength of $440 \mathrm{~nm}$ using a spectrophotometer (UV-1240; Shimadzu, Tokyo, Japan), and the content of phosphorus was detected from the standard curve according to the absorbance value. The average value of the ten measurements was calculated (Zhang 2011).

\section{STATISTICAL ANALYSIS}

Data were analyzed using SPSS v.20.0 software (SPSS Inc., Chicago, IL, USA). The significance of differences between the treatment and control groups was evaluated by one-way analysis of variance. $\mathrm{P}<0.05$ was considered significant (Li et al. 2019).

\section{RESULTS AND DISCUSSION}

EFFECTS OF G. mosseae ON RELATIVE CHLOROPHYLL CONTENT AND NET PHOTOSYNTHETIC RATE OF $X$. italicum Mycorrhizal fungi can accelerate the synthesis and accumulation of carbohydrates and thus improve the photosynthetic capacity of host plant leaves (Doidy et al. 2012). We found here that the relative chlorophyll content of the leaves of $X$. italicum has grown in soil supplemented with $G$. mosseae was 1.69 times higher than that of control plants $(\mathrm{P}<0.001$; Figure 1).

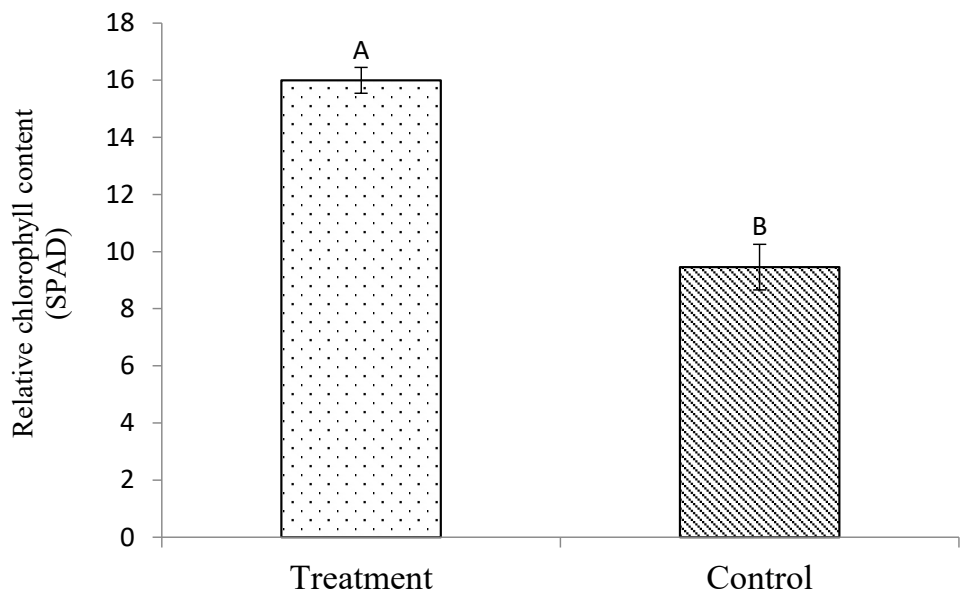

FIGURE 1. Relative chlorophyll content of $X$. italicum has grown in soil with or without $G$. mosseae supplementation. Differences were evaluated by one-way analysis of variance; values with different letters are significantly different $(\mathrm{P}<$ $0.001)$ according to Fisher's least significant difference and Duncan tests $(\mathrm{n}=10)$

In addition, individuals in the treatment group reached the light compensation point at a light intensity of about 20 $1 \mathrm{x}$ as compared to $100 \mathrm{~lx}$ for the control group, indicating that the photosynthetic capacity of $X$. italicum under weak light was enhanced by the presence of $G$. mosseae. The net photosynthetic rate of the leaves of G. mosseae-treated 
$X$. italicum was higher than that in control plants under strong or weak light (Figure 2). Thus, the photosynthetic capacity of $X$. italicum leaves was enhanced by adding $G$. mosseae to the soil. This is consistent with earlier reports (He et al. 2007; Zai et al. 2012) and may be explained by the fact that the accumulation of organic matter in the plant was increased by symbiotic interaction with the fungus (Subramanian et al. 2010). This process may help to increase the relative chlorophyll content in the leaves of $X$. italicum in order to capture more light energy and enhance its photosynthetic ability.

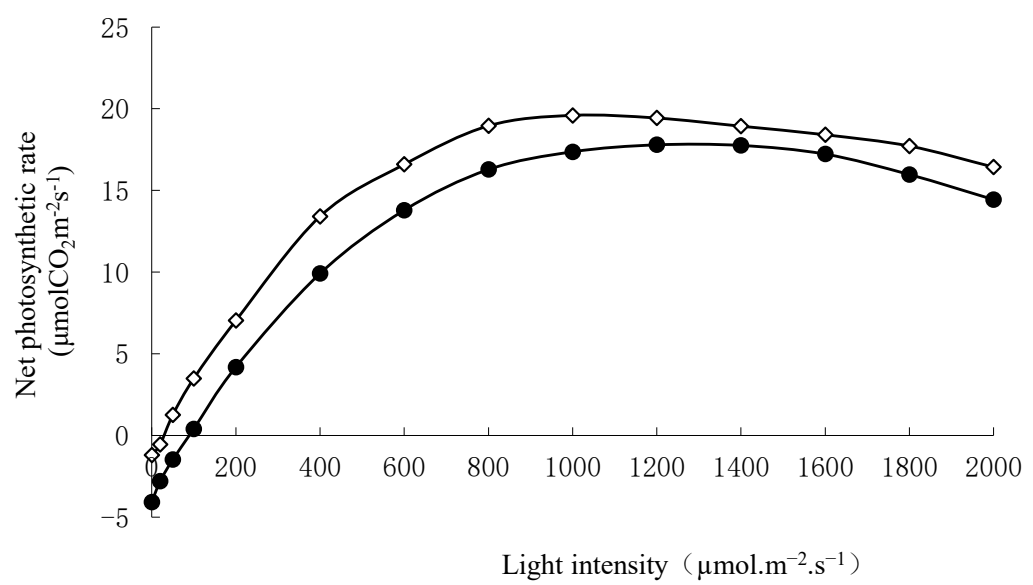

FIGURE 2. Net photosynthetic rate of $X$. italicum has grown in soil with or without $G$. mosseae. Open squares and closed circles represent treatment and control groups, respectively

EFFECT OF G. mosseae ON X. italicum GROWTH

Arbuscular mycorrhizal fungi can enhance the capacity of plant roots to absorb soil moisture and nutrients, thereby, improving water metabolism and promoting plant growth through rhizobial mycelia (Liu et al. 2009). G. mosseae was shown to increase dry matter accumulation in cucumber, tomato, and tobacco seedlings (Liu et al. 2014; Sun et al. 2016; Wang 2003). We found that root length and plant height were increased in the treatment group relative to the control group $(\mathrm{P}=0.003$ and $\mathrm{P}<0.001$, respectively). Similarly, root and stem were 25.6 and $41.8 \%$ longer, respectively, in treated as compared to control plants (Figure 3).

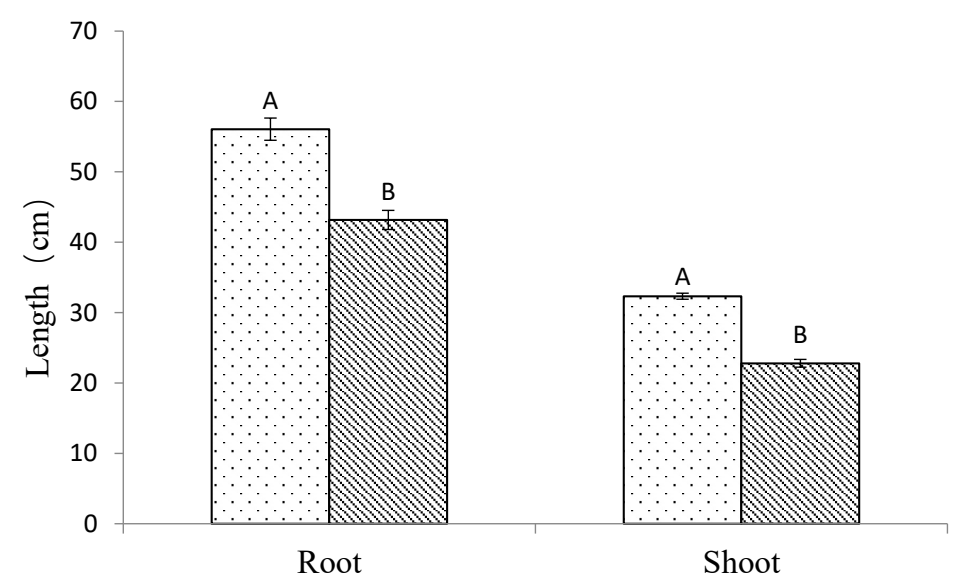

FIGURE 3. Root length and plant height of X. italicum has grown in soil with or without $G$. mosseae. Points and lines with bars represent treatment and control groups, respectively. Differences were evaluated by one-way analysis of variance; values with different letters are significantly different $(\mathrm{P}<0.01)$ according to

Fisher's least significant difference and Duncan tests $(\mathrm{n}=10)$ 
$G$. mosseae also increased the biomass of the roots, stems, and fruits $(\mathrm{P}=0.004, \mathrm{P}=0.006$, and $\mathrm{P}<0.001$, respectively), with 1.6 times higher fruit biomass in the treatment as compared to the control group. On the other hand, there was no significant difference in leaf biomass between the two groups ( $\mathrm{P}=0.356$; Figure 4$)$. The average number of female and male inflorescences per plant was 5.9 and 2.75 times greater in the treatment group than in control plants $(\mathrm{P}<0.001)$, with a female to male inflorescence ratio of $2: 1$ in the former and of 1:1 in the latter (Figure 5). Thus, the association of $G$. mosseae with $X$. italicum not only promoted growth and biomass accumulation, but also increased the number of female and male inflorescences and fruiting capacity. It is especially noteworthy that $G$. mosseae potently stimulated the differentiation of female inflorescences and the reproductive capacity of the host plant.

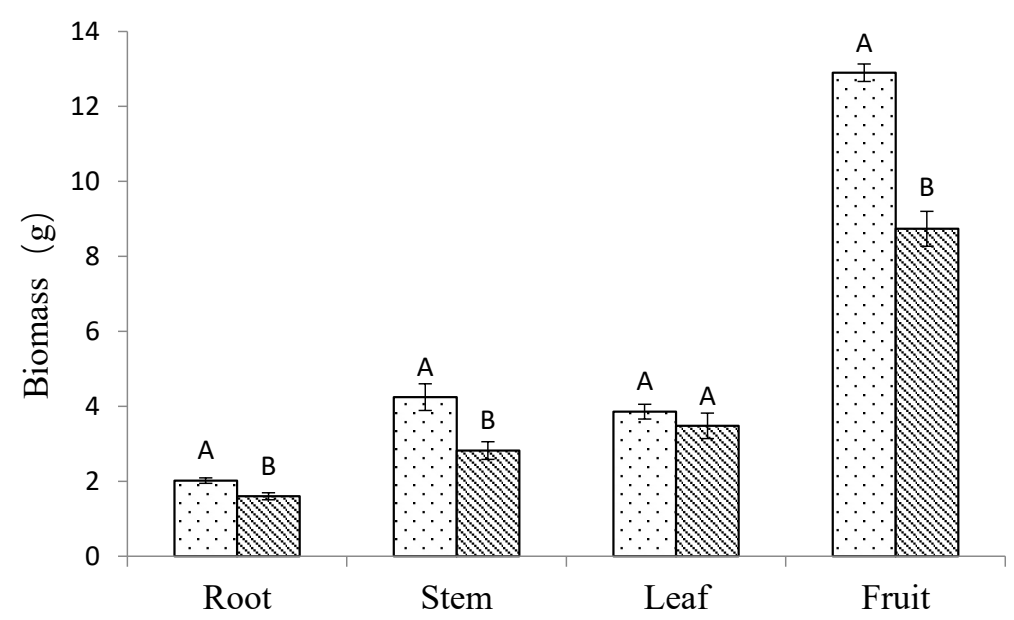

FIGURE 4. Dry weight of organs of X. italicum has grown in soil with or without G. mosseae. Points and lines with bars represent treatment and control groups, respectively. Differences were evaluated by one-way analysis of variance; values with different letters are significantly different $(\mathrm{P}<0.01)$ according to Fisher's least significant difference and Duncan tests $(\mathrm{n}=10)$

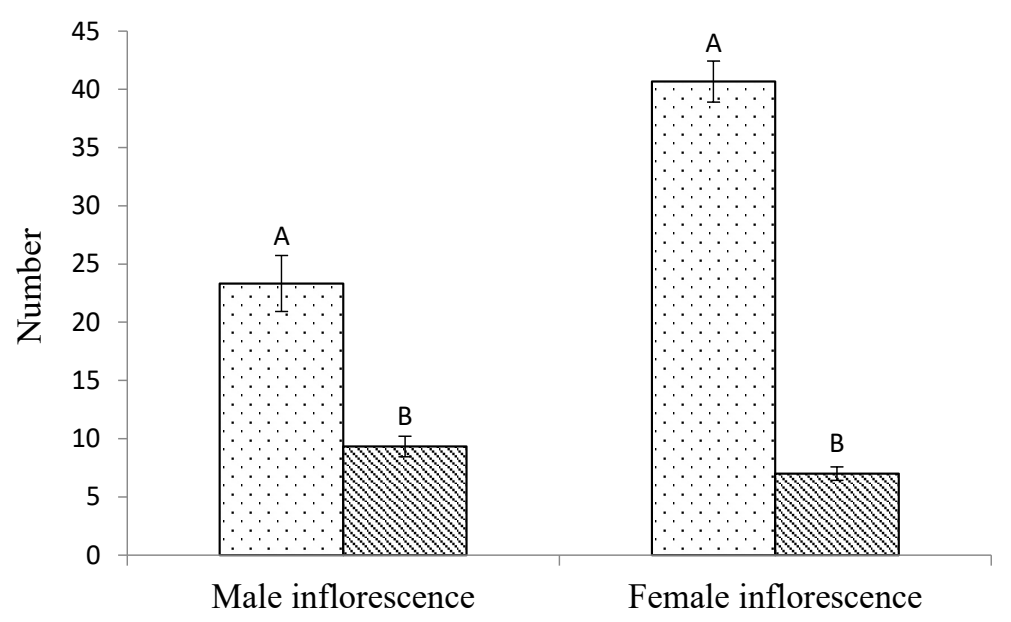

FIGURE 5. The male and female inflorescence number of $X$. italicum has grown in soil with or without G. mosseae. Points and lines with bars represent treatment and control groups, respectively. Differences were evaluated by one-way analysis of variance; values with different letters are significantly different $(\mathrm{P}<0.001)$ according to Fisher's least significant difference and Duncan tests $(\mathrm{n}=10)$ 
EFFECT OF G. mosseae ON PHOSPHORUS CONTENT IN VARIOUS ORGANS OF $X$. italicum

Phosphorus plays an important role in plant respiration and carbohydrate and fat metabolism. Arbuscular mycorrhizal fungi have been shown to enhance the ability of host plants to assimilate low mobility elements such as phosphorus, zinc, and copper in the soil (Marschner 1994), and facilitate the absorption of phosphorus specifically. We determined that phosphorus accumulation in the roots, stems, and leaves were increased in plants grown in G. mosseae-supplemented soil relative to control plants
$(\mathrm{P}=0.011, \mathrm{P}<0.001$, and $\mathrm{P}=0.08$, respectively; Figure 6), as previously reported (Lee et al. 2014). This may be explained by the activation of insoluble phosphate in the soil as a result of a $\mathrm{pH}$ change caused by acid substances such as citric acid secreted by $G$. mosseae, which improved phosphorus uptake and utilization by $X$. italicum (Sun et al. 2016). Nivelle et al. (2018) also reported that some mycorrhizal fungi have the ability to dissolve phosphorus in soil, which is also a fundamental reason why some invasive plants can be used as pioneer plants in special habitats.

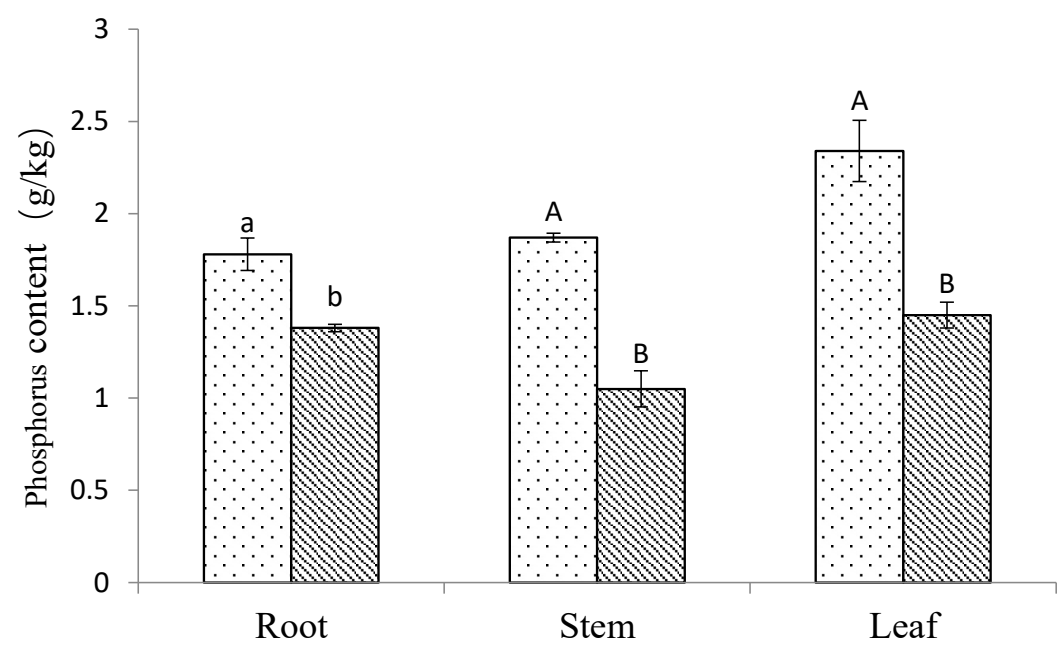

FIGURE 6. Phosphorus content of $X$. italicum has grown in soil with or without $G$. mosseae. Points and lines with bars represent treatment and control groups, respectively. Differences were evaluated by one-way analysis of variance; values with different letters are significantly different $(\mathrm{P}<0.05)$ according to Fisher's least significant difference and Duncan tests $(\mathrm{n}=10)$

Once alien plants successfully settle in the invading area, it is possible to form dominant species through rapid population expansion, which not only results in the change of habitat plant community structure and the loss of biodiversity, but also has a far-reaching and complex impact on the physical and chemical properties of soil and the microbial community and function. Successful invasion by plants depends on the biological characteristics of the species and the invisibility of the habitat - i.e., the abiotic environment and resistance to biological invasion (Chaudhary 2015; Li 2001). In addition to a lack of natural competitors (Cronin et al. 2016) and an empty niche (Johnson 2016) in new areas, mycorrhizal fungi are one of the main determinants of the successful invasion, survival, and expansion of alien plants (Peng 1999).

\section{CONCLUSION}

The results of this study demonstrate that the arbuscular mycorrhizal fungus $G$. mosseae contributes to the establishment of the alien plant species $X$. italicum in new areas by increasing relative chlorophyll content, net photosynthetic rate, and phosphorus accumulation in roots, stems, and leaves of the plant, thereby promoting its growth and survival and conferring it with a competitive advantage over native plants. Moreover, G. mosseae 
increased the number of male and female inflorescences and the ratio of female to male inflorescences, indicating an enhanced reproductive capacity in X. italicum. These results provide insights into the relationship between a mycorrhizal fungus and its host plant that can be useful for developing measures to limit the colonization of new areas by alien plant species that can disrupt the local ecological balance.

\section{ACKNOWLEDGEMENTS}

The study was supported by the National Natural Science Foundation of China, project number: 31360047.

\section{REFERENCES}

Al-Hammadi, M.S., Rashid, A.S. \& Maharachchikumbura, S.S.N. 2018. Molecular identification of fungal pathogens associated with date palm root diseases in the United Arab Emirates. Journal of Plant Pathology 101(2019): 141-147.

Aminah, H., Naimah, C.L., Barizan, R.S.R. \& Noor, M.M. 2013. Effect of light intensity and fertiliser levels on the stock plants of Chengal (Neobalanocarpus heimii) and rooting of its subsequent cuttings. Sains Malaysiana 42(3): 257-263.

Brundrett, M.C. 2009. Mycorrhizal associations and other means of nutrition of vascular plants: Understanding the global diversity of host plants by resolving conflicting information and developing reliable means of diagnosis. Plant and Soil 320(2009): 37-77.

Bunn, R.A., Ramsey, P.W. \& Lekberg, Y. 2015. Do native and invasive plants differ in their interactions with arbuscular mycorrhizal fungi? A meta-analysis. Journal of Ecology 103(6): 1547-1556.

Chaudhary, N., Narayan, R. \& Sharma, D.K. 2015. Differential biomass allocation to plant organs and their allelopathic impact on the growth of crop plants: A case study on the invasibility of Ageratum conyzoides in Indian dry tropics. Indian Journal of Agricultural Sciences 85(11): 1405-1411.

Chmura, D. \& Gucwa-Przepióra, E. 2012. Interactions between arbuscular mycorrhiza and the growth of the invasive alien annual Impatiens parviflora DC: A study of forest type and soil properties in nature reserves (S Poland). Applied Soil Ecology 62(2012): 71-80

Cronin, J.T., Bhattarai, G.P., Allen, W.J. \& Meyerson, L.A. 2016. Biogeography of a plant invasion: Plant-herbivore interactions. Ecology 96(4): 1115-1127.

Doidy, J., Grace, E., Kühn, C., Simon-Plas, F., Casieri, L. \& Wipf, D. 2012. Sugar transporters in plants and in their interactions with fungi. Trends in Plant Science 17(7): 413-422.

Fumanal, B., Plenchette, C., Chauvel, B. \& Bretagnolle, F. 2006. Which role can arbuscular mycorrhizal fungi play in the facilitation of Ambrosia artemisiifolia L. Invasion in France? Mycorrhiza 17(1): 25-35.

Harley, J.L. \& Smith, S.E. 2008. Mycorrhizal symbiosis. Quarterly Review of Biology 3(3): 273-281.

He, Y. \& Ma, M. 2018. Responses of seed germination of the invasive plant Xanthium italicum to environmental factors. Acta Ecology Sinica 38: 1226-1234.
He, Y.J., Jiang, C.H., Yang, H., Wang, Y.J. \& Zhong, Z.C. 2017. Arbuscular mycorrhizal fungal composition affects the growth and nutrient acquisition of two plants from a Karst area. Sains Malaysiana 46(10): 1701-1708.

He, Y.J., Zhong, Z.C., Liu, J.M., Liu, J.C., Song, H.X. \& Jin, J. 2007. Growth response of Broussone tiapapyrifera seedlings to VA mycorrhizal fungi inoculation. Chinese Journal of Applied Ecology 18(10): 2209- 2213.

Johnson, S.D. \& Raguso, R.A. 2016. The long-tongued hawkmoth pollinator niche for native and invasive plants in Africa. Annals of Botany 117(1): 25.

Kazinczi, G., Torma, M., Béres, I. \& Horváth, J. 2009. Competition between Xanthium italicum and crops under field conditions. Cereal Research Communications 37: 77-80.

Lee, M.R., Tu, C., Chen, X. \& Hu, S. 2014. Arbuscular mycorrhizal fungi enhance $\mathrm{P}$ uptake and alter plant morphology in the invasive plant Microstegium vimineum. Biological Invasions 16(2014): 1083-1093.

Li, B., Xu, B.S. \& Chen, J.K. 2001. Perspectives on general trends of plant invasions with special reference to alien weed flora of Shanghai. Biodiversity Science 9(4): 446-457.

Li, J. \& Ma, M. 2019. Seeds over-wintering characteristics of Italian Cocklebur and Stab Cocklebur: Two invasive plants in Xinjiang, China. South African Journal of Botany 121(2019): 216-218.

Lin, H., Zhang, M.L., Wang, P.P. \& Ma, M. 2018. Study on the pollination biology of the invasive plant Xanthium italicum Moretti. Acta Ecology Sinica 38: 1810-1816.

Liu, R.J., Huang, Y. \& Lin, X.G. 2009. Recent advances in the studies of mycorrhizology. Journal of Fungal Research 7(2): 116-124.

Liu, X.L., Xi, X.Y., Shen, H., Liu, B. \& Guo, T. 2014. Influences of arbuscular mycorrhizal (AM) fungi inoculation on the resistance of tobacco to bacterial wilt. Tobacco Science and Technology 49: 23-30.

Marschner, H. \& Dell, B. 1994. Nutrient uptake in mycorrhizal symbiosis. Plant and Soil 159: 89-102.

Nivelle, E., Verzeaux, J. \& Amélie, C. 2018. Effects of glyphosate application and nitrogen fertilization on the soil and the consequences on aboveground and belowground interactions. Geoderma 311(2018): 45-57.

Peng, S.L. \& Xiang, Y.C. 1999. The invasion of exotic plants and the effects of ecosystems. Acta Ecology Sinica 19: 560-568.

Qu, B., Xun, Z.F. \& Xu, Y.F. 2015. The seeds ecological mechanism of Xanthium strumarium invasion. Pratacultural Science 32: 1801-1807.

Shao, H., Huang, X., Wei, X. \& Zhang, C. 2012. Phytotoxic effects and a phytotoxin from the invasive plant Xanthium italicum Moretti. Molecules 17(4): 4037-4046.

Subramanian, K.S. \& Charest, C. 2010. Arbuscular mycorrhizae and nitrogen assimilation in maize after drought and recovery. Physiologia Plantarum 102(2): 285-296.

Sun, X.X., Jin, W.J., Li, Y.S., Yan, Y., Yu, X.C. \& He, C.X. 2016. Effects of two different AMF strains mixture inoculum inoculation on cucumber seedlings grown in the solar greenhouse. China Vegetables 4: 34-37.

Takakura, K.I. \& Fujii, S. 2010. Reproductive interference and salinity tolerance differentiate habitat use between two 
alien cockleburs: Xanthium occidentale and $X$. italicum (Compositae). Plant Ecology 206(2): 309-319.

Wang, C.X., Qin, L., Feng, G. \& Li, X.L. 2003. Effects of three arbuscular mycorrhizal fungi on the growth of cucumber seedlings. Journal of Agro-Environment Science 22: 301-303.

Wang, S.G., Lin, X.G. \& Shi, Y.Q. 2001. Effects of arbuscular mycorrhiza on the resistance of plants to environmental stress. Chinese Journal of Ecology 20: 27-30.

Yang, S.Y., Guo, D.Y., Shen, H.M. \& Zhang, X.H. 2006. Antifungal activity of 14 plants to phytopathogens. Plant Protection 32(3): 68-71.

Zai, X.M., Zhu, S.N., Qin, P., Wang, X.Y., Che, L. \& Luo, F.X. 2012. Effect of Glomus mosseae on chlorophyll content, chlorophyll fluorescence parameters, and chloroplast ultrastructure of beach plum (Prunus maritima) under $\mathrm{NaCl}$ stress. Photosynthetica 50: 323-328.

Zhang, J.X., Bei, Z.G., Zhang, Y. \& Cao, L.K. 2014. Growth characteristics, water and nitrogen use efficiencies of Spinach in different water and nitrogen levels. Sains Malaysiana 43(11): 1665-1671.
Zhang, Y. 2011. Comparative analysis of NPK uptake by different organs of eggplants during different growth stages. Acta Agriculturae Zhejiangensis 23: 1134-1139.

Zhi, G.Y., Chen, X. \& Tang, J.J. 2003. Mediations of arbuscular mycorrhizal fungi on the plant community. Mycosystema 22: 678-682.

Ministry of Education

Key Laboratory of Xinjiang Phytomedicine Resource Utilization College of Life Sciences

Shihezi University

Shihezi, Xinjiang 832003

China

*Corresponding author; email: mamiaogg@126.com

Received: 16 June 2019

Accepted: 13 April 2020 